\title{
Bulletin of the International Union against the Venereal Diseases and Treponematoses
}

\section{9th General Assembly, Leeds, 21-25 May, 1978}

Registration of the delegates took place at the Dragonara Hotel, Leeds, from 12 noon on Sunday, 21 May. One hundred and sixty-nine delegates registered, 48 of them bringing their wives or husbands. A further 30 or so delegates attended the meeting without registering, which brought the total number of delegates to the Assembly to approximately 200, coming from 25 different countries in all parts of the world. The Assembly immediately followed the two-day spring meeting of the Medical Society for the Study of Venereal Diseases in which many IUVDT delegates had taken part.

A meeting of the Executive Council of the IUVDT was held on the afternoon of 21 May and delegates were entertained to a cocktail party in the evening. On the morning of 22 May 12 papers were read on 'Recent advances in microbiology and immunology of gonorrhoea with their practical application including treatment' and in the afternoon a further 11 papers were read on 'Recent advances in the immunology of syphilis'. On 23 May 16 papers were read in the morning and early afternoon on 'Recent advances in the study of STD due to viral and other agents'. In the late afternoon and on the following morning 21 papers were read on 'New trends in the epidemiology of STD'. A detailed programme of the scientific sessions was as follows:

SESSION 1: Theme-Recent advances in microbiology and immunology of gonorrhoea with their practical application including treatment

Theme co-ordinator: Dr Paul Wiesner (USA); Chairmen: Dr A. Reyn (Denmark) and Dr Stuart Brown (USA)

Sensitivity pattern of Neisseria gonorrhoeae to penicillin and screening for $\beta$-lactamase production in Ibadan: A. O. Sogbetun and A. O. Osoba (Nigeria).

Surveillance of $\beta$-lactamase-producing $N$. gonorrhoeae in Africa: P. Piot, M. Duchassin, A. Meheus, Squires C. Bosmans, T. L. Muyembe, M. C. Mupapa, and E. Van Dyck (Belgium).

Antibody responses in gonorrhoea: A. A. Glynn, C. Ison (UK).
Mucosal antibodies in uncomplicated gonococcal infections: A. McMillan (UK).

Penicillin sensitivity of $N$. gonorrhoeae in West Germany: D. Petzoldt, K. Grunder, U. Neubert.

Effect of different preparation procedures on the ultrastructure of gonococci: W. Gebhart, W. Jurecka, J. Söltz-Szöts, J. Thurner, A. Ellinger, and K. Kitz (Austria).

Gonococcal transformations in vivo: P. Novotny (UK). Frequency of urogenital infections of mixed aetiology: gonorrhoea and other infections: A. Siboulet and F. Catalan (France).

Barefoot bacteriological diagnosis of gonorrhoea in areas with limited medical facilities: G. A. Olsen (Denmark).

Spontaneous disappearance of $N$. gonorrhoeae in the tonsillar pharyngeal region: J. Wallin (Sweden), read by Dr Stuart Brown (USA).

Treatment of uncomplicated gonorrhoea in men with single doses of $2.5 \mathrm{~g}$ thiamphenicol (Glitisol): C. Santos (Brazil).

Preservation of the gonococcus by gelatin-disc method: S. Yamai, Y. Obara, T. Nikkawa, Y. Shimoda, and Y. Miyamoto (Japan).

SESSION 2: Theme-Recent advances in the immunology of syphilis

Theme co-ordinator: Dr James N. Miller (USA)

Role of humoral versus cellular mechanisms of resistance in the pathogenesis of human syphilis: M. Metzger (Poland).

Differential lesion development in rabbits from single and graded doses of Treponema pallidum: N. H. Bishop (USA).

Changes following treatment of Borrelia duttoni infection in mice and its relationship with the Jarisch-Herxheimer reaction: D. J. M. Wright (UK).

Comparison of several cardiolipin and treponemal tests in the serodiagnosis of yaws: H. E. Menke, J. Veldkamp, and E. Stolz, E. A. Brunings, P. L. A. Niemel, and A. Notowicz (Holland).

Attenuated yaws in central north Surinam: P. L. A. Niemel, E. A. Brunings, and H. E. Menke (Surinam).

Comparison of the ultrastructure of immunoimmobilised $T$. pallidum and treponemes present in syphilitic patients: H. A. Nielsen, A. Burch-Anderson, and K. HovindHougen (Denmark). 
Recent developments in the serum diagnosis of syphilis: A. Luger (Austria).

Standardisation programme for diagnostic products and tests for syphilis: B. McGrew (USA).

Scheme of IgM and IgG in human venereal syphilis and in experimental treponematoses: P. Hamplen (France).

Evaluation of a double-staining technique for the fluorescent treponemal antibody absorption (FTA-ABS) test: E. F. Hunter, R. M. McKinney, E. Maddison, D. D. Cruce (USA).

The role of cellular hypersensitivity to Treponema pallidum in human syphilis: P. F. Friedman (UK).

SESSION 3: Theme-Recent advances in the study of STD due to viral and other agents

Theme co-ordinator: Dr R. D. Catterall (UK)

Late manifestations of lymphogranuloma venereum: C. N. Sowmini, and K. N. Gopalan (India).

Seroepidemiological study of lymphogranuloma venereum in West Nigeria: A. O. Osoba (Nigeria).

The biology of Trichomonas vaginalis: M. Muller (USA).

Sexually transmitted hepatitis B: F. Lim (UK).

Follow up of patients with hepatitis B surface antigen: P. Simmons (UK).

Group B streptococcal infection: J. Knox (USA).

Herpes simplex-animal model for therapy evaluation: M. Jarratt (USA).

Immunological aspects of herpes genitalis: D. Fanta, and E. M. Kokoschka (Austria).

Vaccination in herpes genitalis: T. Nasemann (West Germany).

Therapeutic aspects of herpes genitalis: J. Söltz-Szöts, D. Fanta (Austria).

Chlamydial genital infection: A. Siboulet, and F. Catalan (France).

Recent advances in serodiagnosis of chlamydial genital infections: J. D. Treharne (UK).

Chlamydial genital infection in certain countries of the Middle East and Africa: S. Darougar, B. Aramesh, N. R. Jones, J. D. Treharne, and A. O. Osoba (UK, Iran, and Nigeria).

Prevalence of chlamydiae in genital infections: H. G. Robson (Canada).

A case of trichomonal vaginitis resistant to metronidazole: J. Thurner, and J. G. Meingassner (Austria).

Condylomata acuminata-therapeutic considerations: E. Gupta (UK).

SESSION 4: Theme-New trends in the epidemiology of STD

Theme co-ordinators: Drs G. Causse, T. Guthe, A. Siboulet (Switzerland, Norway, and France)

Syphilis as viewed from the TPHA test: Y. Onoda and N. Okubo (Japan).

Studies on monospecific FTA-ABS: K. Mizuma, Y. Kataniwa, and T. Sato (Japan).

Therapeutic effect of oral doxycycline in syphilis: Y. Onoda (Japan).
Situation of STD in Latin America: C. Santos (Brazil). An alternative to the problem of insufficient physician manpower in the clinical care of sexually transmitted diseases: C. W. Parton, and S. M. Sgroi (USA). Whither candidosis?: S. S. Bello (Nigeria).

SESSION 5: Theme (cont.)-New trends in the epidemiology of STD

Critical evaluation of the venereal disease control campaign in Poland: J. Towpik (Poland).

Annual Report 1976-Venereal Disease Control Division, South Australia: D. Jorgensen (Australia).

Epidemiology of syphilis and gonorrhoea in New Zealand: W. M. Platts (New Zealand).

Contact in Europe: A. Siboulet (France).

Priorities in a venereal disease control programme: R. L. Persad (Canada).

Current treatment for STD in England and Wales: M. W. Adler (UK).

Does gonorrhoea surveillance pay?: R. C. Rendtorff and H. Packer (USA).

Screening for STD among women attending gynaecological clinics in developing countries: A. Onifade, and A. O. Osoba (Nigeria).

Results of routine screening for STD in Austria over six-year period: D. Fanta, W. Gebhart, W. Gross, E. M. Kokoschka, J. Söltz-Szöts, and J. Thurner (Austria).

Trends in the epidemiology of STD in Tamil Nadu: C. N. Sowmini (India).

Management of a gonorrhoea epidemic far from Montreal: R. Morrisset, S. Kasatea, and G. Tarjan (Canada).

Morbidity of syphilis and gonorrhoea in the internees of the Tokyo detection and classification camp for juvenile delinquents: M. Ashizawa, K. Ito, and M. Ishino (Japan). Non-specific urethritis in developed and developing countries: R. R. Willcox (UK).

Gonorrhoea in Sudanese patients attending venereal diseases clinic in Khartoum: E. E. Omar (Sudan). Illness behaviour and STD: R. M. Harrison (UK).

On the evening of Tuesday 23 May a most impressive and generous reception was given in the Leeds Civic Hall by the Lord Mayor of Leeds.

The General Assembly was held in the afternoon of 24 May and was opened by the President, Dr Axel Perdrup (Denmark), who welcomed the delegates and thanked all those who had helped to make it a success, especially Dr M. A. Waugh, the local organiser, and his staff, Dr J. R. W. Harris, the programme secretary, and the Secretary General, Dr James Jefferiss. The Secretary General then gave his report, saying that he had apologies from Dr Causse of WHO, Professor Canaperia, Professor Hermanns, Dr Vejjabul, and Dr Rajan:

The chief occupation of the Secretary General since our 28th General Assembly in Malta has been the arranging and cancelling of the 29th General Assembly first in 
Mexico City then in Acapulco, and arranging it finally here in Leeds. The Assembly was first to have followed the International Dermatological Congress in Mexico City but was cancelled as it was thought by the Executive Committee that more delegates would be attracted to come to the famous resort of Acapulco after a week in Mexico City. Unfortunately, the arrangements had to be cancelled there too because the hotel where we were to have held the Assembly needed a substantial sum of money deposited five months before the arranged dates. By that time only 18 delegates had paid their registration fee, and we could not risk expending the large sum requested without the assurance that enough delegates would attend so that it would be repaid. However, we have finally got together here.

We had 1000 provisional programmes printed for both Acapulco and Leeds, and we are very grateful to the MSSVD who kindly had over 500 of them sent to their members with their other circulars. The remainder were sent out by the Secretary General.

The Executive Committee met in Vienna from 18 to 20 September 1976. The President called our attention to the grievous loss we had sustained by the death of one of our most active members, Dr Bruce Webster of New York. Various routine matters were then attended to, and Dr Siboulet reported on his work in Europe and South America, suggesting that we should form a Latin American regional office separate from the North American region.

We are very glad to welcome the Australian Department of Health as a new member organisation of our Union as well as several other individual members from that and other countries.

The Union was represented by Dr Michael Waugh at the Montreal Symposium on STD in November 1977.

We have continued our close co-operation with the WHO, which as always is most valuable to us, and I am pleased to say that in March this year Dr Mahler wrote on behalf of WHO to inform us that the Executive Board had decided to maintain official relations with our organisation. Since our last meeting we have sent representatives of our Union, including our President, to the 28th World Health Assembly Technical Discussions in April 1975 on 'Social and Health Aspects of Sexually Transmitted Diseases'-the documents and reports of which were circulated to members.

We have sent representatives to meetings of the regional committees of WHO in the USA, Pakistan, Manila, Thailand, Mexico, and India. The symposium on the 'Surveillance and Control of STD', organised by the regional office for Europe of the WHO was held in Vienna from 21 to 25 September, 1976, where we were represented by our President, Professor Axel Perdrup, and Drs Guthe, Siboulet, and Delune, and several others who were also representing their countries. In addition we have been represented at the 30th and 31st World Health Assemblies in May 1977 and May 1978 by our ex-President and Secretary General, Professor G. A. Canaperia. We are very happy to congratulate him on his recent honour from the World Health Organisation of the Leon Bernard Foundation Award in Social Medicine.
The Treasurer, Dr R. D. Catterall (UK) then reported:

I have the honour once again to present the accounts of the International Union against the Venereal Diseases and Treponematoses for the year ended 31 December, 1977. The financial position of the Union is satisfactory and shows further progress since I last reported to you.

During the year under review subscriptions were received from 80 individual members and from 24 different organisations, but, as has so often happened in the past, there were a number of individuals and several organisations that failed to pay their membership fee, despite reminders on more than one occasion.

Nevertheless, income from subscriptions amounted to $£ 1652$ and interest on our investments totalled $£ 371$, making our total income for the year $£ 2023$, compared with $£ 2165$ in 1976.

The expenses of the Union amounted to $£ 820$ and this includes the sum of $£ 280$ which had to be paid towards the abortive arrangements for the Mexican meeting.

The annual subscription of 191 Korunas was once again paid into the Czechoslovakia Obchodni Bank in Prague. Our credit balance at that bank amounts to the equivalent of $£ 365$ but remains blocked; this amount is not shown in our accounts.

The balance standing to our account at Coutts Bank, London, at 31 December 1977 was $£ 4828$. Total funds of $£ 4761$ have been invested in United Kingdom Government stocks, the interest on which contributes usefully to our income and the capital sum forms a solid basis for our finances.

When the expenses of the Leeds meeting have been met in full it is probable that the balance of our accounts will permit further investments to secure our financial position in the future.

One of the difficulties of the Treasurer is to persuade every individual member to pay his subscription and to ensure that all the member organisations pay their annual contributions. I should like to ask all individual members to arrange for a banker's order or other suitable arrangement so that their subscription is paid automatically each year and for members of the Executive Committee and senior members of the Union to ensure that their national organisation pays its subscription every year.

Our accounts are audited annually by Payne, Stone, Fraser and Co., a firm of Chartered Accountants in London.

The report of the Director of the Regional Office for Europe Dr A. Siboulet (France) should then have been read, but owing to his recall home and a misunderstanding by the Secretary General it was not to hand. However, it is now printed as follows:

Since the last meeting of the Executive Committee, we have made concerted efforts to diffuse health information concerning the communicable sexual diseases to the public and to doctors, and made numerous contacts with specialists of widely different countries, and con- 
tinued to carry out surveys in order to stipulate the best ways of approaching the public.

Thanks to the constant and efficient help of Dr Coulon, General Director of the Alfred Fournier Institute, we have continued to publish and distribute informative material for doctors and the public at large, and many thanks to Dr Durel, General Secretary, LNFCLPV.

The Regional Office has had numerous visits and has maintained contacts:

(1) With the WHO and Dr Causse, more especially as a permanent study on gonococcal infections and their clinical, therapeutic, and epidemiological aspects has been under way since 1961 .

(2) With numerous colleagues during the International Symposium on the urogenital trichomoniasis at Alfred Fournier Institute in 1977 and during 'Le Premier Cours International OMSMST' at Alfred Fournier Institute in 1977.

(3) With the French Health Ministry, who asked us for details on the dangers of sexually transmitted diseases for tourists in 1977 and 1978, and with Professor Perea and Dr Rodrigues (Spain), Professor Delune (Belgium), Dr Stolz (Holland), Dr Franceschini (Italy), Dr Paramanda (Germany), Professor Brault, Professor Morrisset, Dr Tarjan (Canada), Dr Mobarak (Lebanon), and Professor Diop-Mar (Senegal).

(4) With Professor Santos de Goiana (Brazil), President of the new union, Latino-Americana contra las Enfermedades Venereas (Union), who visited the regional office in 1977; Professor José Martins Barros is scientific consultant to this Union.

Concerning the Franco-Swedish sectional pilot study, Dr Martin Bouyer has made known the latest results of this study. It was shown that the probable number of patients suffering from STD was approximately 5000 per year, that is 96 times more than the number of patients declared officially.

With the Comité d'Education Sanitaire et Sociale de la Pharmacie Française et la Ligue Nationale Française contre les Maladies Vénériennes, we have published a pamphlet called 'Il n'y a pas de Maladies Honteuses'.

Under the statutes of the Union, sanitary information must be one of our essential goals and we propose to intensify this effort in the years to come.

In conclusion, the present increase of communicable diseases in Europe and other countries incites us to try to find and take new measures in the fight against these diseases; more than ever a close collaboration between the different regional offices is necessary in order to try to reach the public more and to give doctors precise information, which would be brought up to date each year.

There was no report from the Director General of the Regional Office for the Americas but the report of the Regional Director of the South East Asia and Western Pacific Region was given by Dr C. N. Sowmini (India) in the absence of Dr P. Vejjabul. She reported on the many activities of the Region and the highly successful Regional Conference on
Sexually Transmitted Diseases, held in Singapore in January 1977. The latter was commented on very favourably by Dr R. D. Catterall, who represented the Union on that occasion.

With regard to the Council of Europe Dr Guthe reported that nothing significant had taken place since our last meeting.

Dr M. R. Radovanovic, European Regional Officer for Communicable Diseases of the World Health Organisation, then addressed the Union on behalf of the World Health Organisation. He conveyed greetings to us from the WHO and thanks for inviting him to address us. He apologised for the absence of Dr G. Causse, who was attending the WHO General Assembly at Geneva, where several important matters concerning STD were being discussed. He hoped that we would collaborate with WHO even more than in the past, and especially that our regional offices would collaborate with the widely distributed WHO regional offices in the same parts of the world. He suggested that the IUVDT Regional Office for Europe and the WHO European Regional Office should be in especially close collaboration. He gave as an example the great success of the co-operation of our Executive Committee meeting and the European Regional Office Symposium on the 'Surveillance and Control of STD' at Vienna in September 1977. He suggested that the IUVDT in future should try to arrange their meetings so that they would be continuous with a WHO meeting.

The Secretary General then read the recommendations made by the Executive Committee at their meeting on 21 May 1978 for ratification or otherwise by this 29th General Assembly':

(1a) The formation of a Latin American Region, comprising all countries in the American continent from and including Mexico southwards.

(1b) The formation of a North-American Region comprising USA and Canada.

(1c) That all support possible should be given by this Union to Dr A. O. Osoba (Nigeria) in forming an African Region.

(2) Appointment of officers: President, Dr R. D. Catterall (UK); Secretary General, Dr James Jefferiss (UK) for a further and final year and then Professor Anton Luger (Austria) to take over the office; Treasurer, Dr D. Petzoldt.

(3) Vice Presidents: Dr Pierre Durel; Dr Hubert Delune; Dr Norton Brandao; Dr Thorstein Guthe.

(4) Regional Directors: Europe, Dr André Siboulet; North America, Professor John Knox; Latin America, Professor Corintho Santos; SouthEast Asia and Western Pacific, Dr P. Vejjabul. 
(5) Technical Members of the Council: Dr P. G. Bakker (Netherlands); Dr C. N. Sowmini (India); Professor J. Towpik (Poland); Professor L. Juhlin (Sweden); Professor G. Elste (East Germany); Dr V. S. Rajan (Singapore); Dr J. P. Brault (Canada); Dr L. Nicholas (USA); Dr J. R. W. Harris (UK); Dr A. O. Osoba (Nigeria); Dr D. Jorgensen (Australia); Dr G. Coulon (France); and Dr Y. Onoda (Japan).

(6) That the title 'Permanent Consultants' should be dropped as no place for them appears in the Union's statutes and that the present holders of this title should be known as 'Honorary Members' and that in future those who according to Article 5 in the Statutes have 'Rendered important services to the Union' should be classed as Honorary Members also.

Present Honorary Members and those now proposed: Dr Ambrose King; Dr E. Hermanns; Dr H. Brun-Pedersen; Professor F. Foldvari; Professor G. A. Canaperia; Dr C. S. Nicol; Mrs Josephine V. Tuller; Dr M. Tottie; and Professor Axel Perdrup.

(7) Legal Counsellor: Mr P. Pfeiffer.

(8) Place and date of 30th General Assembly: East Berlin, last week in May 1980, at the invitation of Dr G. Elste (DDR). Themes for the General Assembly to be discussed and finally decided on at Copenhagen 15-16 June 1979. The registration fee for the 30th General Assembly would be $\$ 50$.

All these recommendations were agreed to unanimously. Under 'any other business' $\mathrm{Dr}$ Verling (Eire) invited the Union to hold a future General Assembly in Dublin and Professor Axel Perdrup brought up the matter of the great difficulty in obtaining penicillin (PAM), which is now only made by one manufacturer in the United Kingdom

for export only as its production is uneconomic. The difficulty in obtaining procaine penicillin is almost as great. It had been hoped that benzathine penicillin would take the place of PAM but recent work has suggested that it is not absorbed into the cerebrospinal fluid. Members were asked to urge their own governments to arrange for a supply and Dr Radovanovic was asked to ask the WHO for its help.

Following the General Assembly the Executive Council met again, and among other matters arrangements for the next Executive Council meeting in Copenhagen and the 30th General Assembly in East Berlin were discussed. It was also decided that the practicalities of circulating a news letter should be explored and that if possible a list of members and their addresses should be circulated annually. In view of the very high cost the Union could no longer afford to have simultaneous translation at their Assemblies. It was suggested that all those submitting papers should supply a short summary in French or English, as the case might be, which would be read out to the Assembly.

A very successful banquet was held in the evening, at which Dr T. Guthe spoke warmly of the retiring President Professor Axel Perdrup and thanked him for all the good work he had done for the Union during his term of office. Professor Perdrup replied and thanked all those responsible for the success of this General Assembly and in particular Dr Waugh, the local organiser, to whom he presented a copy of an eighteenth century manuscript on gonorrhoea in view of his interest in the history of medicine.

The final event was a visit to the ancient City of York on the next day, Thursday, 25 May. 